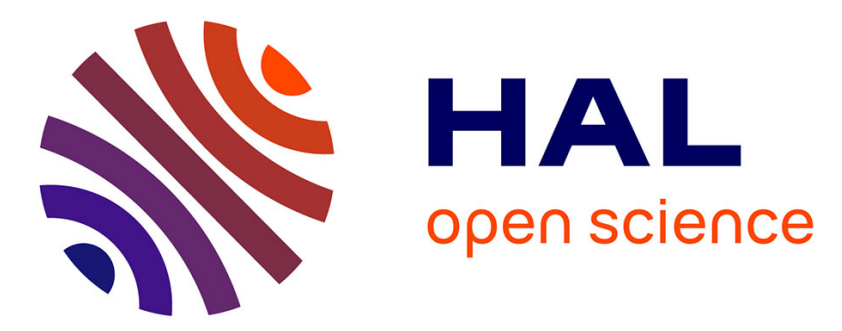

\title{
Radiolytic products study of dicyclohexano 18-crown-6-ether, a selective extractant for nuclear fuel reprocessing
}

\author{
M. Draye, R. Chomel, P. Doutreluigne, A. Guy, J. Foos, M. Lemaire
}

\section{- To cite this version:}

M. Draye, R. Chomel, P. Doutreluigne, A. Guy, J. Foos, et al.. Radiolytic products study of dicyclohexano 18-crown-6-ether, a selective extractant for nuclear fuel reprocessing. Radioanalytical Nuclear Chemistry, 1993, 175, pp.55-62. 10.1007/BF02168369 . hal-00006305

\section{HAL Id: hal-00006305 \\ https://hal.science/hal-00006305}

Submitted on 5 Oct 2021

HAL is a multi-disciplinary open access archive for the deposit and dissemination of scientific research documents, whether they are published or not. The documents may come from teaching and research institutions in France or abroad, or from public or private research centers.
L'archive ouverte pluridisciplinaire HAL, est destinée au dépôt et à la diffusion de documents scientifiques de niveau recherche, publiés ou non, émanant des établissements d'enseignement et de recherche français ou étrangers, des laboratoires publics ou privés.

\section{(c)(1)}

Distributed under a Creative Commons Attribution| 4.0 International License 
RADIOLYTIC PRODUCTS STUDY OF DICYCLOHEXANO-18-CROWN-6, A SELECTIVE EXTRACTANT FOR NUCLEAR FUEL REPROCESSING

\author{
Micheline Draye, ${ }^{a c} \mathrm{R}$. Chomel, ${ }^{\mathrm{a}} \mathrm{P}$. Doutreluingne, \\ A. Guy,b J. Foos ${ }^{b}$, M. Lemaire*c \\ a Service Laboratoire COGEMA, établissement de Marcoule, \\ BP 170, 30205 Bagnols sur Cèze Cédex, France \\ ${ }^{b}$ Laboratoire de Chimie Organique et Dêpartement des \\ Sciences Nucléaires du CNAM, 292 rue Saint Martin, \\ 75141 Paris Cédex 03, France \\ CLaboratoire de Catalyse et Synthèse Organique, \\ U.P. 5401 , UCBL, Bât 308, \\ ESCIL, 43, bd. du 11 Novembre 1918, \\ 69622 Villeurbanne Cédex, France
}

\begin{abstract}
The radiolytic products of the $\mathrm{DCH} 18 \mathrm{C} 6 \mathrm{ob}-$ tained after $\gamma$-irradiation have been determined, and the seven main structures have been separated and analyzed. The radiolytic product yields range from about 0.01 to nearly 0.3 molecules per $100 \mathrm{eV}$ absorbed by the DCH18C6 at an energy of $3290 \mathrm{kGy}$. From the viewpoint of radiation decomposition rate, the $\mathrm{DCH} 18 \mathrm{C} 6$ presents a considerable resistance and its radiolytic products have little or no extraction power.
\end{abstract}

\title{
INTRODUCTION
}

Complexing properties of the DCH18C6 and its applications in various fields of chemistry have been widely

\footnotetext{
* To whom all correspondence should be addressed.
} 
studied. Thus, the possibility of strontium or plutonium separation from medium and high activity used nuclear fuel and the extraction of radioactive strontium contained in water by the $\mathrm{DCH} 18 \mathrm{C} 6$ has been demonstrated ${ }^{1-3}$.

In addition, the considerable radiation resistance of solid DCH $18 \mathrm{C} 6$ has been shown ${ }^{4,5}$ and the modifications observed after exposure to $\gamma$-irradiation of DCH18C6 chloroform solution have been attributed to the chloroform radiolytic products ${ }^{5}$. However, there is still no definite information on the behavior of DCH18C6 under the action of ionizing radiation and no information on the nature of its radiolytic products.

The present work is concerned with the study of the structural determination of radiolytic products on DCH18C6 $\gamma$-irradiation. For each compound, we have reported the number of molecules formed per $100 \mathrm{eV}$ of energy absorbed by the DCH18C6, i.e. the "G" values.

\section{EXPERIMENTAL}

The DCH18C6 cis-syn-cis isomer was separated from its other isomer by the method described previously ${ }^{6}$.

The samples were made up of $0.2 \mathrm{~g}$ of cis-syn-cis DCH $18 \mathrm{C} 6$ and $2 \mathrm{ml}$ of uranyl nitrate $\left(20 \mathrm{~g} \mathrm{U}^{-1}\right)$ aqueous solution in $1 \mathrm{~N}$ nitric acid. They were irradiated with a ${ }^{137} \mathrm{Cs} \gamma$-source in corked glass flasks. The absorbed energy was, after calibration, $3290 \mathrm{kGy}$ at a dose rate of $19.6 \mathrm{kGy} \cdot \mathrm{h}^{-1}$.

After irradiation, to each sample were added $2 \mathrm{ml}$ of $\mathrm{CH}_{2} \mathrm{Cl}_{2}$ and $20 \mathrm{ml}$ of distilled water. The aqueous phase was extracted with 3 portions of $25 \mathrm{ml} \mathrm{CH}_{2} \mathrm{Cl}_{2}$.

NMR experiments were carried out on a Bruker AC 200 spectrometer operating at $200.132 \mathrm{MHz}\left({ }^{1} \mathrm{H}\right)$ and 50.323 
MHz $\left({ }^{13} \mathrm{C}\right)$ under broadband proton decoupling; trifluoroacetic acid was introduced to identify $\mathrm{OH}$ functions.

FTIR spectra were recorded on a 1720-X Perkin Elmer spectrometer.

The radiolysis products were separated on a Delsi DI 700 chromatograph equipped with a spiral FJ 1592 nonpolar capillary column (25 $\mathrm{m} \times 0.22 \mathrm{~mm}$ i.d.) coated with $100 \%$ of dimethylsiloxane stationary phase, and they were analyzed on a mass spectrometer Nermag $R$ 10-10H at $70 \mathrm{eV}$. Two methods of ionization, viz. electron impact and chemical positive ionization with $\mathrm{NH}_{3}$ were used.

\section{RESULTS AND DISCUSSION}

The FTIR results are given in Table 1.

The presence of ether and alcohol functions was confirmed by NMR, but no carbonyl function was identified.

Using gas chromatography, seven radiolytic products and the DCH18C6 were separated and analyzed by mass spectrometry; the characteristic masses obtained are summarized in Table 2 .

Masses were identified by chemical ionization. The structures were distinguished by fragmentation analysis using electron impact. For example, compounds B and C, although having the same mass, differ in their structure: with the electron impact, the ion I is characteristic of the structure $B$ and the ion $J$ is characteristic of the other structure C (see Table 3).

The radiolytic product structures of dicyclohexano18-crown-6 are given in Table 4 .

Structures $A$ and $C$ turned out to be the principal products of DCH18C6 radiolysis when the energy absorbed by the crown ether is $3290 \mathrm{kGy}$. 
TABLE 1

FTIR data of dicyclohexano-18-crown-6 and its radiolytic product mixture

\begin{tabular}{cc}
\hline Frequency, $\mathrm{cm}^{-1}$ & Corresponding vibration \\
\hline 3402 & vOH bonded \\
2937 & vas $\mathrm{CH}_{2}$ \\
2867 & vs $\mathrm{CH}_{2}$ \\
1734 & vs $\mathrm{C}$ very weak \\
& O \\
1450 & $v \mathrm{CH}_{2}$ \\
1099 & $v \mathrm{CH}_{2}-\mathrm{O}_{2} \mathrm{CH}_{2}$ \\
736 & $\rho \mathrm{CH}_{2}$ \\
\hline
\end{tabular}

$\nu=$ stretching, $\rho=$ rocking, $a=$ asymmetric,

$\mathbf{s}=$ symmetric.

TABLE 2

Chemical ionization mass spectral data for radiolytic products of dicyclohexano-18-crown-6

\begin{tabular}{cccc}
\hline Compound & $\mathrm{M}+1$ & $\mathrm{M}+18$ & \multicolumn{1}{c}{$\begin{array}{c}\text { Corresponding } \\
\text { molecule composition }\end{array}$} \\
\hline B & 161 & 178 & $\mathrm{C}_{8} \mathrm{O}_{3} \mathrm{H}_{16}$ \\
C & 205 & 212 & $\mathrm{C}_{10} \mathrm{O}_{8} \mathrm{H}_{20}$ \\
D & 205 & 212 & $\mathrm{C}_{10} \mathrm{O}_{8}{ }^{\mathrm{H}} 20$ \\
E & 249 & 266 & $\mathrm{C}_{12} \mathrm{O}_{5}{ }^{\mathrm{H}} 24$ \\
F & 293 & 310 & $\mathrm{C}_{14} \mathrm{O}_{6}{ }^{\mathrm{H}} 28$ \\
$\mathrm{H}$ & 303 & 320 & $\mathrm{C}_{16}{ }^{\mathrm{O}}{ }_{5} \mathrm{H}_{30}$ \\
DCH 18C6 & 347 & 364 & $\mathrm{C}_{18} \mathrm{O}_{6} \mathrm{H}_{34}$ \\
\hline
\end{tabular}


TABLE 3

Characteristic fragments of structures B and C

Ion I Ion J

The values of the radiochemical yields, G, are listed in Table 5 .

The sum of $G$ values corresponding to the seven main products is 0.75 . For the number of DCH18C6 molecules disappeared for $100 \mathrm{eV}$ absorbed, we found a value of 0.72 which is comparable to 0.75 . Thus, if this macrocycle has to be used in radioactive medium, the molecular structures described in Table 3 could be considered as impurities produced during the process. No radiolytic products have a macrocyclic structure, and the dramatically lower complexing and extracting properties of open chain polyethers compared to the macrocyclic "analogs" has been demonstrated ${ }^{7}$. For example, the complexation of the $\mathrm{K}^{+}$and $\mathrm{Ba}^{2+}$ by the 18-crown-6 is, respectively, 9,000 and 55,000 times as high as with the pentaglyme.

DCH18C6 possesses high stability towards radiolysis: the power of the dose received during our experiments (3290 kGy) is 11 times as high as the one estimated during a reprocessing campaign, but nevertheless $50 \%$ of DCH18C6 remains unchanged. 
TABLE 4

Radiolysis product structures of dicyclohexano-18-crown-6

\begin{tabular}{|c|c|c|}
\hline Compound & $\mathrm{m} / \mathrm{z}$ & $\begin{array}{c}\text { Corresponding molecule } \\
\text { composition }\end{array}$ \\
\hline A & 160 & \\
\hline B & 204 & \\
\hline C & 204 & \\
\hline D & 248 & \\
\hline E & 292 & \\
\hline $\mathrm{F}$ & 302 & \\
\hline $\mathrm{H}$ & 346 & \\
\hline DCH $18 \mathrm{C} 6$ & 372 & \\
\hline
\end{tabular}




\section{TABLE 5}

Product yields from the radiolysis of dicyclohexano-18-crown-6, molecules/100eV

\begin{tabular}{cc}
\hline Compound & Molecules/100 eV \\
A & 0.29 \\
B & 0.04 \\
C & 0.23 \\
D & 0.06 \\
E & 0.03 \\
F & 0.01 \\
H & 0.09 \\
$A+B+C+D+E+F+H$ & $\Sigma G=0.75$ \\
\hline
\end{tabular}

On the other hand, its radiolytic products give rise to molecules exhibiting very poor extracting properties contrary to that demonstrated for TBP ${ }^{8}$.

We are grateful to Mr. J.M. Garvey for excellent technical assistance.

\section{REFERENCES}

1. E. Blasius, W. Klein, U. Schön, J. Radioanal. Nucl. Chem., 89 (1985) 389 .

2. V.V. Yakshin, E.F. Myasoedov, O.M. Vilkova, A.M. Tuzova, A.T. Fedorova, I.M. Radionova, Radiokhimiya,

3. M. Lemaire, A. Guy, R. Chomel, J. Foos, J. Chem. Soc., Chem. Commun, (1991) 1152 . 
4. S.V. Zatonsky, O.S. Povoloskaya, J. Radioanal. Nucl. Chem., Lett., 117 (1992) 361.

5. L. Mattel, T. Bilbao, J. Radioanal. Nucl. Chem., Lett., 137 (1989) 183.

6. V. Guyon, P. Drognat Landré, A. Guy, J. Foos, M. Lemaire, Chemistry Lett., (1992) 723 .

7. B.G. Cox, H. Schneider, Coordination and Transport Properties of Macrocyclic Compounds in Solution, Elsevier Publishing Company (1992) p. 87.

8. M. Isaac, The Use of Tri-n-butyl Phosphate in Plutonium Extraction. Radiolysis and Recycling of the Solvent, CEA 2349 (1963). 